\title{
Antioxidant and antimicrobial activities of the methanolic extracts of some edible seed spices
}

\author{
DeyaEldeen Mohammed Radwan ${ }^{1,3 *}$, Ashraf Mohammed Mohammed Essa ${ }^{2,3}$ and Dia Mohammed \\ Soltan ${ }^{1}$ \\ ${ }^{1}$ Botany Department, Faculty of Science, Sohag University, Sohag, Egypt \\ ${ }^{2}$ Botany Department, Faculty of Science, Fayoum University, Fayoum, Egypt \\ ${ }^{3}$ Biology Department, Faculty of Science, Jazan University, Jazan, Saudi Arabia
}

Rec. 29 Aug, 2017 Accept. 12 Oct, 2017

\begin{abstract}
This study was conducted to screen the antioxidant and antimicrobial activities of the methanolic extracts of ten types of edible seeds that are used commonly as food additives and beverages. Contents of flavonoids, polyphenols and ascorbate as well as total antioxidant activity of extracts were analyzed. At the same time, the antimicrobial activities were performed against different bacterial and fungal strains. Extracts of Cuminum cyminum and Pimpinella anisum showed the highest values of polyphenols while elevated levels of flavonoids and ascorbic acid were recorded in Linum usitatissimum, Piper nigrum, Pimpinella anisum and Portulaca oleraceae extracts. The tested extracts demonstrated a high capability to scavenge DPPH free radicals at levels above 89\%. Furthermore, seed extracts of Piper nigrum, Brassica alba, recorded a remarkable antibacterial activities against wide range of bacterial strains. Simultaneously, the seed extracts of Coriandrum sativum, Cuminum cyminum, Piper nigrum and Nigella sativa recorded high potentiality to inhibit the growth of various fungal strains. It can be concluded that Cuminum cyminum, Linum usitatissimum, Piper nigrum, Pimpinella anisum, Coriandrum sativum and Nigella sativa seeds could have beneficial impacts on human health as a result of their high antioxidant and antimicrobial activities.
\end{abstract}

Keywords:

Antioxidant activity; antimicrobial activity; ascorbic acid; edible seeds; flavonoids; polyphenols.

Abbreviations:

DPPH, 1,1-diphenyl-2-picrylhydrazyl radicals; AsA, Ascorbic acid; TAA, total antioxidant activity; GAE, gallic acid equivalents; $\mathrm{CE}$, catechin equivalent

\section{Introduction:}

Although edible seed spices are added to food to convey aroma, taste, flavor, color and pungency, they have been reported to have an important task as ordinary method of food preservation due to their antioxidant and antimicrobial properties (Hashem and Alamri, 2010). Plant seeds contain a wide range of metabolites that play a key role in the protection of plants against insects and pathogenic microorganisms. The antioxidant and antimicrobial compounds are beneficial to support human health and prevent common diseases. An antioxidant compound can be defined as a compound which inhibits oxidation by either scavenging the reactive oxygen species (ROS) to yield harmless products and/or by disrupting free radical chain reactions (Valacchi and Davis, 2008). Reactive oxygen species (ROS) are present in toxic forms such as superoxide anion, hydroperoxyl and hydrogen peroxide that are involved in the oxidative stress (Carocho and Ferreira, 2013). Most of the antioxidant compounds produced with large amounts in plants and stored in seeds. Many of seeds that are used as food additives are rich source of antioxidant compounds such as polyphenols

\footnotetext{
* Corresponding author:

Dr. DeyaEldeen Mohammed Radwan

凶deya90@yahoo.com
} 
flavonoids and vitamins. Extracts from seeds and other plant parts have antioxidant and antimicrobial properties (Wilson, 2016). Presence of antioxidants in human food can serve as a defensive factor against free radicals in the human body.

It is well known that many polyphenol compounds such as phenolic acids and flavonoids which possess remarkable antioxidant activities are present in large amounts in plant materials (Radwan et al., 2010). Some studies have shown positive correlation of the increased dietary intake of natural antioxidants with the reduced coronary heart disease and cancer mortality as well as with longer life expectancy (Halliwell, 2007). Furthermore, many polyphenol compounds demonstrated many health-benefit properties such as antioxidant, anticancer, antiviral, free radicals scavengers, anti-inflammatory activities, and an ability to inhibit human platelet aggregation (Mohsen and Ammar, 2009).

Flavonoids are group of phenolic compounds that protect the cell against lipid peroxidation. At present, more than 4000 flavonoids are known, and this structural diversity is reflected in a variety of biological functions such as pigments, antioxidants, phytoalexins and allelochemicals. Furthermore, flavonoids have been suggested to play a preventive role in the development of cancer and heart disease (Jiménez et al., 2015).

Ascorbic acid is of great importance in biochemical reactions as a reducing agent. For example, recycling of antioxidants such as vitamin $\mathrm{E}$ by AsA has been shown to be protective against oxidative stress (Barış et al., 2011).The role of AsA as a ROS scavenger in cells and as a cofactor in structural protein organization is well known. Ascorbate is water soluble compound, known as vitamin $\mathrm{C}$, is an important antioxidant where it was shown to react not only with hydrogen peroxide, but also with $\mathrm{O}_{2}{ }^{-}, \mathrm{OH} \bullet$, and lipid hydroperoxides (Sharma et al., 2012). Moreover, Brunton et al. (2006) reported that reducing agents such ascorbate and the development of reducing enzyme systems such as superoxide dismutase can catalyze the reduction of superoxide radicals.
The antimicrobial compounds found in plants are of great interest because antibiotic resistance is a worldwide public health concern especially in terms of food-borne illness and nosocomial infections (Mora et al., 2005). Plant products can prevent food deterioration through reducing oxidative rancidity of lipids, bacteriostatic or bactericidal activities and fungistatic or fungicidal effect. At the moment, many phytochemicals are used in the treatment of various pathogenic microorganisms (Agrawal et al., 2012).

It has been reported that Piper nigrum extract inhibited the growth of a variety of microorganisms such as Bacillus subtilis, Pseudomonas aeruginosa, Aspergillus niger, Candida albicans and Saccharomyces cervisisae (Sasidhran and A.N., 2010). Similarly, the antimicrobial activity of seed extract of Cuminum cyminum and Pimpinella anisum has been reported against various bacterial and fungal isolates. At the same time, A. graveolens and $C$. sativum had been mentioned to have a potent antimicrobial action against various microbial cells including Gram-positive, Gram-negative bacteria and pathogenic fungi (Hassanen $\mathrm{et} \mathrm{al}$., 2015).

Salman et al. (2008) studied the antibacterial activity of $N$. sativa against various clinical bacterial isolates that are resistant to a number of antibiotics. They reported that 97 out of 144 tested strains were completely inhibited by the oil of black cumin. Meanwhile, the methanolic extract of $N$. sativa exhibited a potent inhibitory effect of fungal growth of Aspergillus, Candida, Cryptococcus and Issatchenkia species (Raval et al., 2010).

This work was to proof that edible seed spices can be used not only for their taste and flavor but also for their antioxidant and antimicrobial properties that consequently supports human health. In addition, this study was to compare the amounts of antioxidant compounds contained in the tested seed in relation to their antioxidant and antimicrobial activities. 


\section{Materials and methods:}

Plant materials, sample preparation and extraction:

Seeds produced by the species listed in table (1) were air dried at room temperature to constant weights. The dried materials were separately ground to powders with a bladecarbide grinding (IKA-WERK Type: A: 10). Twenty grams of powdered seeds in triplicate sub-samples were soaked in petroleum ether $\left(60{ }^{\circ} \mathrm{C}\right.$ for $10 \mathrm{hrs}$ ) to remove the oil fraction. The crude extracts were then extracted in 100 $\mathrm{ml}$ of methanol separately for $48 \mathrm{hrs}$. on an orbital shaker. Extracts were filtered using a Buckner funnel and Whatman No. 1 filter paper. Each filtrate was concentrated to dryness under reduced pressure. Starting concentration was (2\% of the total weight of seeds). Each extract was re-suspended in methanol to make a $50 \mathrm{mg} / \mathrm{ml}$ stock solution (Mau et al., 2001).

\begin{tabular}{lll}
\hline Scientific name & Tamily name & Common name \\
\hline Nigella sativa & Ranunculaceae & Black Cumin \\
Limum usitatissimum & Linaceae & Linseed \\
Portulaca oleraceae & Portulacaceae & Purslane \\
Coriandrum sativum & Apiaceae & Coriander \\
Curum curvi & Apiaceae & Caraway \\
Cuminum cyminum & Apiaceae & Cumin \\
Piper nigrum & Piperaceae & Black Pepper \\
Apium gravenlens & Apiaceae & Celery \\
Brassica alba & Brassicaceae & White Mustard \\
Pimpinella anisum & Apiaceae & Anise \\
\hline
\end{tabular}

Table 1.List of plant species produced the edible seeds used in this experiment.

\section{Total Phenolics content:}

Total polyphenols content of seed powder extracts were determined using FolinCiocalteau reagents (Singleton and Rossi, 1965). Gallic acid standard solution (2.0 $\mathrm{mg} / \mathrm{ml}$ ) was prepared by dissolving $0.01 \mathrm{~g}$ in $50 \mathrm{ml}$ of distilled water. The solution was then diluted to give with concentrations working standard solutions of $1.5,1.0,0.5,0.2$, and 0.1 $\mathrm{mg} / \mathrm{ml}$. Forty microlitres of extract (in $80 \%$ methanol) or gallic acid standard was mixed with $1.8 \mathrm{ml}$ of Folin-Ciocalteu reagent (previously diluted 10-fold with distilled water) and allowed to stand at room temperature for $5 \mathrm{~min}$, and then $1.2 \mathrm{ml}$ of sodium bicarbonate $(7.5 \% \mathrm{w} / \mathrm{v})$ was added to the mixture. After standing $60 \mathrm{~min}$ at room temperature, absorbance was measured at 765 $\mathrm{nm}$. Results are expressed as mg GAE/g DW where GAE is gallic acid equivalents.

\section{Total flavonoids content:}

Total flavonoid content was measured in the methanolic extracts of powdered seeds according to the method of (Dewanto et al., 2002). The methanolic extracts were diluted and mixed with $75 \mu 1 \mathrm{NaNO}_{2}(5 \%)$. After6 $\min , 150 \mu 1$ of $10 \% \mathrm{AlCl}_{3}$ and $500 \mu \mathrm{l}$ of $\mathrm{NaOH}$ $(1 \mathrm{M})$ were added to the mixture. Finally, the mixture was adjusted to $2.5 \mathrm{ml}$ with distilled water. The absorbance versus prepared blank was read at $510 \mathrm{~nm}$. Total flavonoid contents of seed extract were expressed as $\mu \mathrm{g}$ of catechin equivalents per gram of dry weight (mg CE/g DW) through the calibration curve with catechin.

\section{Ascorbic acid content:}

According to the method of (Hewitt and Dickes, 1961), AsA contents of seed extracts were analyzed. A known weight of seeds was grounded to a powder, and extracted in 5\% perchloric acid. The homogenate was centrifuged at $12,000 \mathrm{~g}$ for $2 \mathrm{~min}$, and the supernatant was neutralized with $5 \mathrm{M}$ potassium carbonate using methyl orange indicator. The neutralized supernatant was centrifuged again and used for the AsA assay. Standard solutions were prepared by dissolving 40- $100 \mathrm{mg}$ of AsA in $100 \mathrm{ml}$. of $2 \%(\mathrm{w} / \mathrm{v})$ dithizone extracted meta-phosphoric acid. Suitable portions were taken as soon as po

ssible, the $\mathrm{pH}$ was adjusted to 6-8 with a predetermined amount of trisodium phosphate and the volume made up to a convenient amount before measurement of absorption at $265 \mathrm{~nm}$.

\section{Antioxidant activities:}

Methanolic extracts of seeds were subjected to the free radical-scavenging activity assay using the method described by (Shimada et al., 1992). Each extract (0.2-10 $\left.\mathrm{mg} \mathrm{ml}^{-1}\right)$ in methanol $(2 \mathrm{ml})$ was mixed with 2 $\mathrm{ml}$ of freshly prepared methanolic solution 
containing $100 \mathrm{ppm}$ of 1,1-diphenyl-2picrylhydrazyl (DPPH) radicals. The mixture was shaken vigorously and left to stand for 30 min in the dark. The absorbance was then measured at $517 \mathrm{~nm}$. The percentage of DPPH scavenging activity was calculated according to the following formula:

DPPH scavenging ability $=\left[1-\left(\mathrm{A}_{\mathrm{i}}-\mathrm{A}_{\mathrm{j}}\right) / \mathrm{Ac}\right]^{*}$ 100.

Where, $A_{i}$ is absorbance of extract + DPPH, $A_{j}$ is absorbance of extract + methanol, and Ac is absorbance of DPPH + methanol. A lower absorbance indicates a higher scavenging effect.

Antibacterial activity of the methanolic extract of seeds:

The antibacterial activity of methanolic extract of the tested seeds was assayed against the various bacterial strains including; Escherichia coli, Klebsiella pneumoniae, Pseudomonas aeruginosa, Bacillus subtilis, Erwinia carotovora, Bacillus brevis, Streptomyces parvulus and Staphylococcus aureus. The evaluation of antibacterial activity was performed using standard agar disc diffusion method (Brooks and Orston, 2002). Filter paper discs were impregnated with $10 \quad 1$ of seed extracts and left to dry. The loaded discs were applied carefully to the surface of the seeded agar plates using sterile forceps. The experiment was carried out in five replicates and the diameters of the zones of inhibition were measured by millimeter scale after 24 hours of incubation at $37^{\circ} \mathrm{C}$. The results were compared with broad spectrum antibiotics (streptomycin at $100 \mathrm{mg} / \mathrm{ml}$ ) as a positive control. Furthermore, disc was prepared using $95 \%$ methanol instead of seed extracts for negative control.

Antifungal activity of the methanolic extracts:

Fungicidal activity of the seed extracts was carried out by employing disc diffusion method (Esteban et al., 2005), against Fusarium oxysporum, Pythium ultimum, Aspergillus flavus, Aspergillus niger, Rhizoctonia solani, Alternaria solani and Candida albicans. These strains were provided by the City of Science \& Technology (Cairo, Egypt) except Candida albicans that was obtained from Fayoum University Hospitals
(Fayoum, Egypt). These fungal strains were cultured into potato dextrose agar (Merck, Germany). Seven day-old cultures were covered with $1 \mathrm{ml}$ distilled water and the colonies were probed with the tip of a sterile Pasteur pipette to obtain a mixture of mycelium and spores (Essa and Khallaf, 2014). The fungal suspensions were adjusted with a spectrophotometer set at $65 \%$ transmittance and 530nm. $200 \mu \mathrm{l}$ of fungal suspension was spread on the PDA medium plates. After $10 \mathrm{~min}$, discs saturated with the different seed extracts were placed on the Petri dishes. Then Petri dishes were incubated at $28^{\circ} \mathrm{C}$ and the inhibitory activity of each extract was examined at intervals of $24 \mathrm{~h}$. Nystatine $(0.3 \mathrm{mg} / \mathrm{ml})$ was used as a positive control while discs saturated with $95 \%$ methanol after drying were used as a negative control. After the colonies grew, the inhibition zones around the disks were measured and the average of five replicates was recorded.

\section{Statistical analysis:}

The results are reported as mean \pm SD of three independent replicates. Statistical analyses of data were carried out by computer using SPSS ver. 22.0 software. One-way ANOVA and Duncan's New Multiple-range test were used to the differences among the means (Duncan, 1951). $P$-values less than 0.05 were considered significant.

\section{Results}

\section{Antioxidant properties:}

a) Total Phenolic contents:

Total polyphenols content present in seed extracts were analyzed and shown in Fig 1A. The results revealed that the extracts of $C$. cyminum, A. graveolens and $P$. anisum seeds had the highest contents of phenolic compounds among the tested extracts. The values were 55,50 and $49 \mathrm{mg}$ GAE/g DW seed powder, respectively. Almost similar contents were found in P. oleraceae, B. alba, L. usitatissimum and P. nigrum. Furthermore, the extracts of $N$. sativa, C. sativum and $C$. carvi seeds were the lowest in there phenolics content. These contents were 23.93, 27.36 and $28.23 \mathrm{mg}$ GAE/g DW seed powder, respectively.

b) Total flavonoids: 
The amount of flavonoids varied in different types of seed extracts. Total flavonoids were determined as catechin equivalents in milligrams per gram of dry weight (mg CE/g DW). It is ranged from 9.8 to $19.5 \mathrm{mg} \mathrm{CE} / \mathrm{g}$ DW (Fig. 1B). The highest values reached 19.5, 19.34, 18.24 and 17.84 $\mathrm{mg} \mathrm{CE} / \mathrm{g}$ DW which recorded with the extracts of $L$. usitatissimum, $P$. nigrum, $P$. anisum and $P$. oleraceae, respectively. Moreover, the contents of flavonoids ranged from 14.6-17.4 $\mathrm{mg} \mathrm{CE} / \mathrm{g}$ DW in the extracts of $B$. alba, $C$. carvi, A. graveolens and C. cyminum. On the other hand, Negilla sativa seed extract recorded the lowest content of flavonoids followed by $C$. sativum and the analyzed values were 9.85 and $11.36 \mathrm{mg} \mathrm{CE} / \mathrm{g} \mathrm{DW}$, respectively.

c) Ascorbic acid:

The content of AsA found in seeds extracts were analyzed and presented in Fig (1C). Most of those extracts had high amounts of ascorbate. Among those, C. cyminum, $L$. usitatissimum, $P$. nigrum, $P$. anisum and $A$. graveolens had the highest amounts (above 5 $\mathrm{mg} / \mathrm{g}$ DW). C. sativum and $N$. sativa were the lowest in their ascorbate content. In detail, the values of ascorbate for those extracts were 2.9, 3.4 , and $3.46 \mathrm{mg} / \mathrm{g} \mathrm{DW}$, respectively.

d) Total antioxidant activity:

The total antioxidant activity (TAA) was demonstrated in all methanolic extracts of seeds and the results were shown in figure 1D. The antioxidant activities of all seed extracts represented values above $89 \%$. It is clear that several seed extracts had more antioxidants metabolites and hence their antioxidant activities were high and the ability for scavenging DPPH free radicles was increased. Among those seed extracts, $P$. oleraceae, $P$. nigrum had the highest percentage (94 and
93\%) in their antioxidant activities. Moreover, B. alba and L. usitatissimum scavenged 92.7 and $92 \%$ of DPPH free radicals. The extracts of $A$. graveolens, $C$. cyminum and $C$. carvi had almost similar values (91\%) of antioxidant activities. The lowest extracts in their antioxidant activates were $N$. sativa, $C$. sativum and $P$. anisum extracts. Generally all these seed extracts had amounts antioxidants which revealed high antioxidant activities.

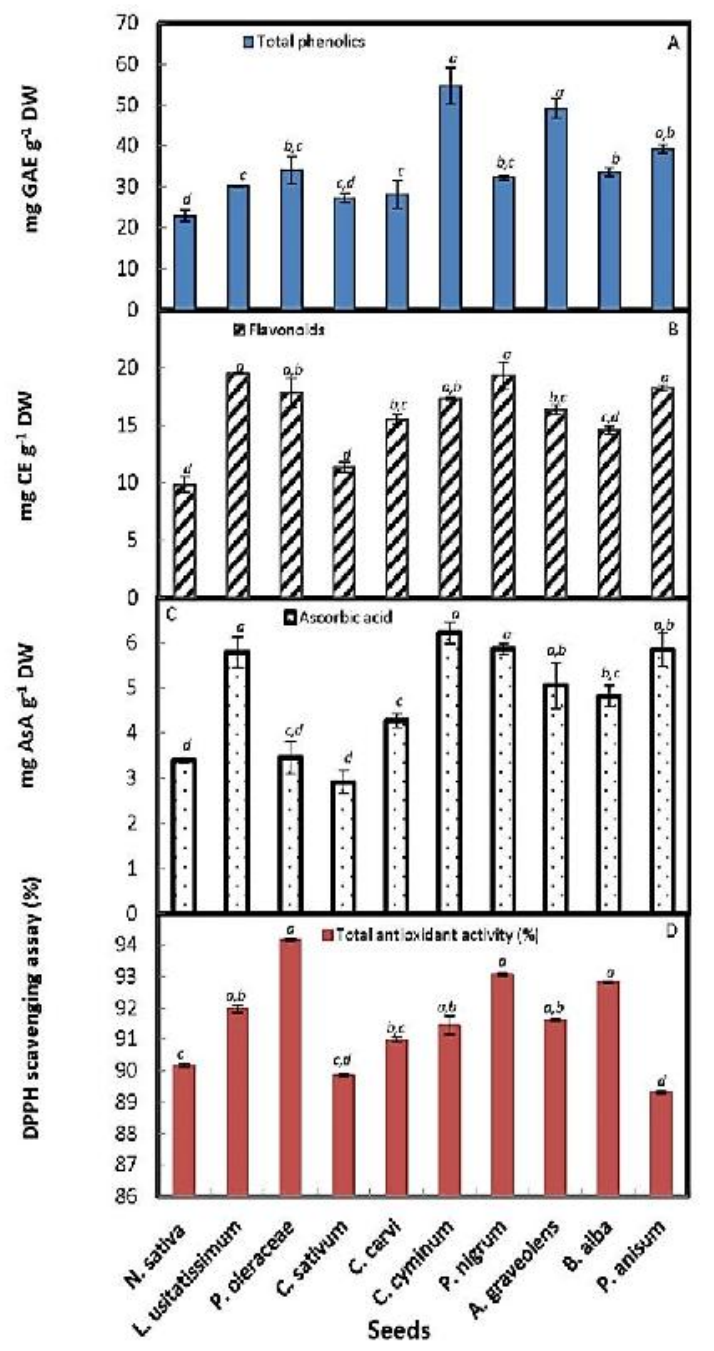

Figure1. Evaluation of antioxidant activities of methanolic extracts of some common edible seeds. Polyphenols (A); Flavonoids (B); Ascorbic acid (C) and Total antioxidant activity (D). 


\begin{tabular}{cccccc}
\hline & & PPH & FLV & AsA & TAA \\
\hline PPH & Pearson Correlation & 1 & 0.422 & $0.586^{* *}$ & 0.052 \\
& Sig. (2-tailed) & & 0.064 & 0.007 & 0.829 \\
& N & 20 & 20 & 20 & 20 \\
\hline FLV & Pearson Correlation & 0.422 & 1 & $0.730^{* *}$ & $0.471^{*}$ \\
& Sig. (2-tailed) & 0.064 & & 0.000 & 0.036 \\
& N & 20 & 20 & 20 & 20 \\
\hline AsA & Pearson Correlation & $0.586^{* *}$ & $0.730^{* *}$ & 1 & 0.071 \\
& Sig. (2-tailed) & 0.007 & 0.000 & & 0.766 \\
& N & 20 & 20 & 20 & 20 \\
\hline TAA & Pearson Correlation & 0.052 & $0.471^{*}$ & 0.071 & 1 \\
& Sig. (2-tailed) & 0.829 & 0.036 & 0.766 & 20 \\
& N & 20 & 20 & 20 & \\
\hline & $* *$ Correlation is significant at the 0.01 level (2-tailed). & \\
\hline & $*$ Correlation is significant at the 0.05 level (2-tailed). & \\
\hline
\end{tabular}

Table 2.Correlations between the analyzed antioxidant activities. PPH; polyphenols; FLV, flavonoids; AsA, ascorbic acid; TAA, total antioxidant activity.

A clear relationship between the level of the antioxidant compounds; polyphenols, flavonoids, ascorbic acid and total antioxidant activity was detected and presented in table 2 . From the results, the content of AsA is significantly correlated with the presence of both polyphenols and flavonoids. Moreover, a significant correlation between total antioxidant activity and flavonoids contents was recorded.
Antibacterial activities of the seed extracts:

The obtained results (Table 3) clarified that most of the seeds extracts showed a potential antibacterial influence against the tested bacterial strains in comparison to the positive control (100 $\mathrm{mg} / \mathrm{mL}$ streptomycin). The maximum bacterial inhibition was recorded with the extracts of $P$. nigrum, B. alba and $N$. sativa. The seed extract of $P$. nigrum demonstrated a marked inhibition of both Gram-negative and Gram-positive bacterial strains at various levels.

\begin{tabular}{lllllllll}
\hline Seed extract & $\begin{array}{l}\text { Escherichia } \\
\text { coii }\end{array}$ & $\begin{array}{l}\text { Erwinia } \\
\text { carotovora }\end{array}$ & $\begin{array}{l}\text { Kiebsiellap } \\
\text { neumoniae }\end{array}$ & $\begin{array}{l}\text { Pseudomonas } \\
\text { aeruginosa }\end{array}$ & $\begin{array}{l}\text { Streptomyces } \\
\text { Parvulus }\end{array}$ & $\begin{array}{l}\text { Staphylococals } \\
\text { aureus }\end{array}$ & $\begin{array}{l}\text { Bacillus } \\
\text { brevis }\end{array}$ & $\begin{array}{l}\text { Bacillus } \\
\text { subtilis }\end{array}$ \\
\hline Streptomycin & $24.2 \pm 0.4$ & $22.8 \pm 0.8$ & $26.6 \pm 0.5$ & $30.6 \pm 0.4$ & $25.2 \pm 0.9$ & $24.8 \pm 0.9$ & $22.8 \pm 0.7$ & $29.4 \pm 1.4$ \\
Nigella sativa & $21.8 \pm 0.3$ & $20.4 \pm 0.1$ & $22.8 \pm 0.6$ & $26.2 \pm 0.6$ & $15.4 \pm 0.3$ & $12.6 \pm 0.8$ & $12.4 \pm 0.9$ & $13.2 \pm 0.9$ \\
Linum usitatissimum & $17.6 \pm 0.8$ & $13.4 \pm 0.5$ & $10.4 \pm 0.6$ & $11.4 \pm 0.6$ & $15.2 \pm 0.5$ & $20.8 \pm 0.7$ & $17.6 \pm 0.6$ & $16.6 \pm 0.7$ \\
Portulaca oleraceae & - & $11.6 \pm 1.0$ & - & $10.0 \pm 1.1$ & - & - & $09.4 \pm 0.8$ & $11.4 \pm 0.9$ \\
Coriandrum sativum & $17.2 \pm 0.4$ & $13.0 \pm 0.3$ & $18.2 \pm 0.4$ & $11.8 \pm 0.6$ & $13.8 \pm 0.7$ & $10.0 \pm 0.4$ & $14.8 \pm 0.2$ & $12.8 \pm 0.4$ \\
Carum carvi & $09.4 \pm 0.3$ & $10.2 \pm 0.4$ & $10.0 \pm 0.7$ & $11.4 \pm 0.8$ & $11.6 \pm 0.6$ & $8.6 \pm 0.7$ & - & $09.6 \pm 0.3$ \\
Cuminum cyminum & $13.6 \pm 0.5$ & $11.0 \pm 0.5$ & $14.8 \pm 0.7$ & - & $16.0 \pm 0.6$ & $12.8 \pm 0.3$ & $18.2 \pm 0.5$ & $15.0 \pm 0.9$ \\
Piper nigrum & $22.8 \pm 0.7$ & $26.6 \pm 0.3$ & $27.0 \pm 0.3$ & $21.0 \pm 0.3$ & $26.4 \pm 0.4$ & $23.4 \pm 0.5$ & $24.8 \pm 0.4$ & $23.2 \pm 0.5$ \\
Apium graveolens & $16.4 \pm 0.2$ & $22.4 \pm 0.4$ & $18.6 \pm 0.9$ & $17.2 \pm 0.9$ & $19.2 \pm 0.3$ & $11.8 \pm 0.3$ & $22.6 \pm 0.7$ & $14.6 \pm 0.8$ \\
Brassica aiba & $24.0 \pm 0.5$ & $26.8 \pm 0.7$ & $23.6 \pm 0.7$ & $24.8 \pm 0.3$ & $23.6 \pm 0.8$ & $19.0 \pm 0.8$ & $20.8 \pm 0.3$ & $24.4 \pm 0.8$ \\
Pimpinella anisum & $19.2 \pm 0.7$ & $21.2 \pm 0.5$ & $18.8 \pm 0.1$ & $18.4 \pm 0.2$ & $11.4 \pm 0.5$ & $15.2 \pm 0.7$ & - & $20.0 \pm 0.9$ \\
\hline
\end{tabular}

Table 3. Evaluation of antibacterial activity of the methanolic seed extracts against different Gram-negative and Grampositive bacteria using standard agar disc diffusion method. The diameters of the zones of inhibition were measured by millimeter. Streptomycin $(100 \mathrm{mg} / \mathrm{mL})$ was used as a positive control while a disc prepared by $95 \%$ methanol instead of seed extracts was used as negative control. 
The recorded percentage of growth inhibition was $118.1 \%$ with E. carotovora, $109.2 \%$ with B. brevis, $104.0 \%$ with $S$. Parvulus, $103.7 \%$ with $K$. pneumoniae, $95.8 \%$ with $S$. aureus, $91.7 \%$ with $E$. coli,79.3\% with $B$. subtilis and $70.1 \%$ with $P$. aeruginosa. Likewise, $B$. alba extract showed astonishing suppression in the bacterial growth of $E$. carotovora $(118.2 \%)$, E. coli $(100 \%), S$. parvulus $(92.1 \%)$, B. brevis $(90.9 \%), \quad P$. aeruginosa (89.3\%), K. pneumonia (88.5\%), B. subtilis $(82.8 \%)$ and S. aureus $(79.2 \%)$. Similarly, the extract of Nigella sativa showed a significant retardation of the bacterial growth of E. carotovora (90.9\%), E. coli (87.5\%), P. aeruginosa (87.7\%), K. pneumoniae (84.6\%), $S$. parvulus $(60.2 \%)$, B. brevis $(54.5 \%), S$. aureus $(50 \%)$ and B. subtilis $(44.8 \%)$. At the same time, the lowest antibacterial activity was recorded with the seed extracts of $P$. oleraceae and C. carvi. This study demonstrated a broad spectrum antibacterial activity of $P$. nigrum, $B$. alba and $N$. sativa seed extracts against Gram-negative and Gram-positive bacteria (Table 3).
Antifungal properties of the seed extracts:

The obtained data (Table 4) showed that seed extracts of $C$. sativum, C. cyminum, $P$. nigrum and $N$. sativa have the highest antifungal potentialities against the tested fungal strains in comparison with nystaine ( 0.3 $\mathrm{mg} / \mathrm{mL}$ ) as a positive control. Regarding $C$. sativum the recorded inhibition of fungal growth was $93.1 \%$ with $R$. solani, $92.9 \%$ with C. albicans, $82.1 \%$ with A. flavus, $74.1 \%$ with $P$. ultimum, $67.7 \%$ with $F$. oxysporum and $66.7 \%$ with $A$. niger. In respect of $P$. nigrum, the maximum suppression of fungal growth was recorded against $A$. flavus (89.3\%), $C$. albicans (82.1\%), P. ultimum (80.6\%), A. solani (71.9\%), A. niger (70.1\%). Similarly, the seed extract of $C$. cyminum showed high antifungal impact against $F$. oxysporum (74.2\%), A. niger $(70.1 \%)$ and A. solani $(65.6 \%)$. At the same time, $N$. sativa showed a clear antifungal activity against $A$. niger (76.7\%), A. flavus $(75.0 \%)$ and C. albicans (71.4\%). It is worth to mention that some of the tested seed extracts showed no antifungal activities such as $P$. anisum against $F$. oxysporum, $P$. ultimum, A. solani, C. albicans; $P$. oleraceaea against A. flavus, $R$. solani, $P$. ultimum and $N$. sativa against $R$. solani.

\begin{tabular}{|c|c|c|c|c|c|c|c|}
\hline Seed extract & $\begin{array}{l}\text { Aspergillus } \\
\text { flav's }\end{array}$ & $\begin{array}{l}\text { Aspergillus } \\
\text { niger }\end{array}$ & $\begin{array}{l}\text { Fusarium } \\
\text { oxysporum }\end{array}$ & $\begin{array}{l}\text { Rhizoctonia } \\
\text { solani }\end{array}$ & $\begin{array}{l}\text { Alternaria } \\
\text { solani }\end{array}$ & $\begin{array}{l}\text { Pythium } \\
\text { uitimum }\end{array}$ & $\begin{array}{l}\text { Candida } \\
\text { albicans }\end{array}$ \\
\hline Nystaine & $28.6 \pm 0.4$ & $31.0 \pm 0.3$ & $31.8 \pm 0.7$ & $29.8 \pm 0.3$ & $32.2 \pm 0.6$ & $31.4 \pm 0.5$ & $28.6 \pm 0.4$ \\
\hline Nigella sativa & $21.4 \pm 0.7$ & $23.6 \pm 0.8$ & $16.6 \pm 0.4$ & - & $19.0 \pm 0.2$ & $16.6 \pm 0.4$ & $20.2 \pm 0.6$ \\
\hline Linum usitatissimum & $12.0 \pm 0.9$ & $11.4 \pm 0.6$ & $15.4 \pm 0.6$ & $18.2 \pm 0.7$ & $20.0 \pm 0.6$ & $11.0 \pm 0.3$ & $14.8 \pm 0.5$ \\
\hline Portulaca oleraceae & - & $12.8 \pm 0.5$ & $11.2 \pm 0.3$ & - & $10.2 \pm 0.4$ & - & $11.0 \pm 0.8$ \\
\hline Coriandrum sativum & $23.6 \pm 0.5$ & $20.2 \pm 0.8$ & $21.0 \pm 0.4$ & $27.4 \pm 0.8$ & $18.5 \pm 0.4$ & $23.2 \pm 0.3$ & $26.8 \pm 0.6$ \\
\hline Carum carvi & $13.0 \pm 0.4$ & $11.6 \pm 0.5$ & $16.2 \pm 0.2$ & $19.8 \pm 0.6$ & $12.8 \pm 0.6$ & $14.0 \pm 0.8$ & $17.2 \pm 0.5$ \\
\hline Cuminum cyminum & $18.8 \pm 0.3$ & $21.4 \pm 0.3$ & $23.6 \pm 0.5$ & $17.0 \pm 0.3$ & $21.8 \pm 0.3$ & $18.4 \pm 0.7$ & $16.6 \pm 0.4$ \\
\hline Piper nignum & $25.2 \pm 0.7$ & $21.2 \pm 0.5$ & $19.2 \pm 0.3$ & $15.4 \pm 0.7$ & $23.2 \pm 0.5$ & $25.8 \pm 0.4$ & $23.8 \pm 0.8$ \\
\hline Apium graveolens & $11.0+0.6$ & $12.0+0.3$ & $14.8+0.2$ & $18.4+0.5$ & $13.0+0.7$ & $11.0+0.3$ & $10.2+0.6$ \\
\hline Brassica alba & $13.8 \perp 0.4$ & $18.6 \perp 0.7$ & $11.0 \perp 0.9$ & $11.2 \perp 0.2$ & $12.4 \perp 0.6$ & $14.8 \perp 0.3$ & $17.4 \perp 0.9$ \\
\hline Pimpinella anisum & $10.6 \pm 0.6$ & $11.8 \pm 0.6$ & - & $12.4 \pm 0.6$ & - & - & - \\
\hline
\end{tabular}

Table 4. Evaluation of antifungal activity of the methanolic seed extracts against different fungal strains using disc diffusion method (Esteban et al., 2005). The experiment was carried out in triplicate and the diameters of the zones of inhibition were measured by millimeter. Nystaine $(0.3 \mathrm{mg} / \mathrm{ml})$ was used as a positive control while a disc prepared by $95 \%$ methanol instead of seed extracts was used as negative control. 


\section{Discussion:}

Using of food additives as dressings is very common in most countries. Not only can the taste of food be changed by additives but also its nutritional value. Among natural sources of food additives, seeds are commonly used for their antioxidant and antimicrobial properties. Seeds contain a variety of polyphenolic compounds that traditionally have shown to be effective in protecting the lipids within the seeds from oxidation (Murcia et al., 2001). In this work, the crude methanolic extracts of seeds were found to contain amounts of polyphenols ranged from (23-55 mg GAE/g DW). The highest contents of phenolic compounds were detected in extracts of $C$. cyminum, A. graveolens and $P$. anisum, $P$. oleraceae, B. alba, L. usitatissimum and $P$. nigrum seeds. Obviously, extracts of $N$. sativa, C. sativum and C. carvi seeds were the lowest in their phenolic contents. Previously, Wangensteen et al., (2004) reported $19 \mathrm{mg}$ $\mathrm{GAE} / \mathrm{g}$ total phenolic compounds in some coriander plants. Moreover, Muchuweti et al. (2007) recorded values of polyphenols between 6.9 and $15.83 \mathrm{mg} \mathrm{GAE} / \mathrm{g}$ are present in some selected food additives. It is well known that, polyphenols have many health benefits which led to the formulation of dietary supplements. The possible action of natural antioxidants in suppressing or eradicating oxidative stress has been studied by many scientists (Srinivasan, 2014). Natural antioxidants are used against aging and other diseases relates to free radical mechanisms. These compounds are considered powerful antioxidants function against free radicals. The free radicals are any chemicals that contain atoms with an unpaired electron in its outer orbit. The unpaired electron in free radical can be located in any atom. In contrast, free radicals that are part of ROS only have the unpaired electron on the oxygen atom. ROS and other free radicals have the same characteristics, i.e., a short life, instability, and the ability to react with other molecules to achieve stability, which can lead to cellular damages(Sharma et al., 2012).

Variable amounts of flavonoids (9.8 - 19.5 $\mathrm{mg} \mathrm{CE} / \mathrm{g} \mathrm{DW}$ ) were detected in the tested seed extracts. Extracts of L. usitatissimum, $P$. nigrum, $P$. anisum and $P$. oleraceae recorded the highest values. Moreover, the contents of flavonoids of B. alba, C.carvi, A. graveolens and $C$. cyminum were ranged from 14.6-17.4 mg CE/g DW. It's well known, flavonoids are considered one of the most health beneficial natural compounds produced in seeds. In details, flavonoids could inhibit plasma platelet aggregation and cyclooxygenase activity, the suppression of histamine release, potent nitric oxide radical scavenging activity and exhibiting antibacterial, antiviral, antiinflammatory and antiallergenic effects. Also, flavonoids could terminate the radical chain reactions that occur during the oxidation of triglycerides in food systems (fats, oils and emulsions) and thus can act as free radical scavengers (Turkoglu et al., 2007). Furthermore, enzymes such as superoxide dismutase, catalase and glutathione peroxidase are the main system that opposes oxidation. If the free radicals production becomes more than the capacity of enzymatic system, the second line of defense (vitamins; such as AsA) may come to action (Halliwell, 2007).

All species that do not synthesize AsA such as humans require it as part of their nutrition. Small quantities of AsA are sufficient to prevent and cure scurvy; however, larger quantities may be required to maintain good health during conditions of adverse environment, physiological stress, and certain diseases(McDowell, 2008). In the present work, the tested extracts had high amounts of ascorbate. For example, C. cyminum, $L$. usitatissimum, $P$. nigrum, $P$. anisum and $A$. graveolens had higher levels of AsA (above 5 $\mathrm{mg} / \mathrm{g}$ DW). Moreover, C. sativum and $N$. sativa were the lowest in their ascorbate content. AsA can inactivate harmful free radicals produced through normal cellular activity and from various stressors. In the process of sparing fatty acid oxidation, tocopherol is oxidized to the tocopheryl free radical. AsA can donate an electron to the tocopheryl free radical, regenerating the reduced antioxidant form of tocopherol (McDowell, 2008).

In this experiment, except for $(P$. oleraceae) which had the highest value of total antioxidant activity among the tested seeds, it 
was found that, seeds which had higher amounts of polyphenols, flavonoids and AsA, were found to have a higher antioxidant activity when subjected to DPPH free radical scavenging assay. Most of extracts managed to scavenge DPPH radical to above $89 \%$. Seed extracts of $P$. oleracea and $P$. nigrum had the highest antioxidant activities (94 and 93\%) and $B$. alba and L. usitatissimum scavenged 92.7 and $92 \%$ of DPPH free radicals. On the other hand, $N$. sativa, $C$. sativum and $P$. anisum extracts had the lowest values of antioxidant activates among the tested samples. In harmony with that Muchuweti et al. (2007) recorded an antioxidant capacity of some edible seeds exceeded $75 \%$ by DPPH assay. The use of moderate amounts of these seeds could improve human health via providing the body with necessary amounts of antioxidant and vitamins. All selected seeds in this experiment retrieve healthful benefits. For instance, treatment with $N$. sativa extract prior to infection with coronavirus decreases the replication of this virus. Furthermore, cumin (C. cyminum) has stomachic, diuretic, carminative and antispasmodic properties (Chen et al., 2014).

The contents of antioxidant compounds (polyphenols, flavonoids, ascorbic acid) and total antioxidant activity of seed extracts were strictly correlated. For example, a significant correlation between total antioxidant activity and flavonoids contents was detected. Moreover, AsA content is significantly correlated with both polyphenols and flavonoids. Previously, Shui and Leong (2006) reported strong correlation between the TAA and total phenolic content of some fruits. Consequently the antioxidant properties of the tested extracts was mainly related to the presence of high levels of flavonoids.

The extent of antimicrobial resistance among pathogenic microorganisms has produced vast clinical complexity in the treatment of infectious diseases. Consequently, there is a huge necessity to look for innovative antimicrobial agents that should be safe and less expensive and more effective against pathogenic organisms to substitute the ineffective ones. This study demonstrated a broad spectrum antibacterial activity of $P$. nigrum, $B$. alba and $N$. sativa seed extracts against Gram-negative and Gram-positive bacteria. The antibacterial action of the $B$. alba extracts is correlated with the observations of previous study (Dubey et al., 2014). Likewise, the high antimicrobial efficacy of $P$. nigrum against bacteria has been reported (Ahmad et al., 2012). Also, the antimicrobial activity of $N$ sativa crude extracts against microorganisms has been demonstrated by several research groups (Salman et al., 2008). At the same time, the present study demonstrated a high capability of $C$. sativum, C. cyminum, P. nigrum and Nigella sativa seed extracts to inhibit the growth of different fungal strains. The capability of $C$. sativum, $C$. cyminum, $P$. nigrum and $N$. sativa seed extracts to inhibit the growth of different fungal strains are in harmony with previous study that highlighted the antifungal activity of $C$. sativum and C. cyminum and $P$. nigrum and $N$. sativa (Rogozhin et al., 2011). The potent antimicrobial activity of the seed extracts could be attributed to their content of polyphenolic and flavonoids compounds. These bioactive metabolites that belong to phenolic compounds mainly serve as plant defense mechanisms or are known to be synthesized by plants in response to microbial infection (Mohammed et al., 2012). It is known that phenolic compounds have many medicinal properties, among them the antimicrobial, antioxidant and antiinflammatory (Harborne and Williams, 2000). Several studies have proved the biocidal action of plant phenolic compounds against various aerobic microbial strains including Candida sp., Klebsiella pneumoniae, Salmonella enterica, Staphylococcus sp. and anaerobic strains (Hong et al., 2006).

The mechanism of antimicrobial action of phenolic compounds is still unclear but various assumptions have been postulated including hydrogen bonding of phenolic compounds to membrane proteins followed by partition in the lipid bilayer, disruption of membrane and inhibition of membrane embedded enzymes and destruction of electrons transport systems (Raybaudi-Massilia et al., 2009). In addition to 
the detrimental effect of phenolic compounds on the cell membranes, seed extracts could contain other secondary metabolites that inhibit the synthesis and activity of some essential enzymes leading to a disruption of the metabolic activity of the microbial cell (Khan and Nasreen, 2010).Human gut microbiota plays an important role in multiple host functions including fortification against pathogenic microorganisms and release of essential bioactive compounds. Diet is a chief aspect that influences on the population dynamics of gut microbiota (Tzounis et al., 2008). Actually, the microbial conversion of phenolic compounds leads to the production of a vast array of metabolites that may have beneficial effects on human health (Blaut and Clavel, 2007).

\section{Conclusion:}

To sum up, the tested seed extracts which are used as food additives in our daily food had both antioxidant and antimicrobial activities at variable levels. The antioxidant activity of the extracts of these seeds might be attributed to higher contents of phenolic compounds and flavonoids as well as ascorbic acid. Among the tested seed extracts $C$. cyminum and $P$. nigrum as well as $P$. anisum had the highest contents of antioxidants.

Seed extracts of $P$. nigrum, $B$. alba and $N$. sativa demonstrated a broad spectrum antibacterial activity against the tested Gramnegative and Gram-positive bacteria. Meanwhile a high antifungal potentiality was recorded with $C$. sativum, $C$. cyminum, $P$. nigrum and $N$. sativa seed extracts. It can be concluded that intake of these seeds as food additives in our daily food could improve human health due to their antioxidant and antimicrobial activities.

\section{Conflicts of Interest:}

We declare that we have no conflicts of interest.

\section{References:}

Agrawal, M.K., Varma, A., Varma, A., Goyal, S. (2012). In vitro and in vivo antibacterial activity of Lantana camara (leaves) against the pathogen causing skin diseases ie Staphylococcus aureus. Indian J. App.
Pure Bio. 27:279-286.

Ahmad, N., Fazal, H., Abbasi, B.H., Farooq, S., Ali, M., Khan, M.A. (2012). Biological role of Piper nigrum L.(Black pepper): A review. Asian Pac. J. Trop. Biomed. 2:1945-1953.

Barış, D., Kızıl, M., Aytekin, Ç., Kızıl, G., Yavuz, M., Çeken, B., Ertekin, A.S. (2011). In vitro antimicrobial and antioxidant activity of ethanol extract of three Hypericum and three Achillea species from Turkey. Int. J. Food Prop. 14:339-355.

Blaut, M., Clavel, T. (2007). Metabolic diversity of the intestinal microbiota: implications for health and disease. The J. Nutr. 137:751S-755S.

Brooks, G.F., Orston, L.N. (2002). Jawetz, Melnick and Adelberg's Medical Microbiology. $2^{\text {nd }}$ ed. Appelton and Lange, Norwalk Connect/Los Altos, California.

Brunton, L.L., Lazo, J.S., Parker, K.L. (2006). Goodman \& Gilman's the pharmacological basis of therapeutics. United States of America: Mac GrawHill.

Carocho, M., Ferreira, I.C. (2013). A review on antioxidants, prooxidants and related controversy: Natural and synthetic compounds, screening and analysis methodologies and future perspectives. Food Chem. Toxicol. 51:15-25.

Chen, Q., Gan, Z., Zhao, J., Wang, Y., Zhang, S., Li, J., Ni, Y. (2014). In vitro comparison of antioxidant capacity of cumin (Cuminum cyminum L.) oils and their main components. LWTFood Sci. Tech. 55:632-637.

Dewanto, V., Wu, X., Adom, K.K., Liu, R.H. (2002). Thermal processing enhances the nutritional value of tomatoes by increasing total antioxidant activity. J. agri. food chem. 50:3010-3014.

Dubey, S., Agrawal, M.K., Sharma, R. (2014). Investigation of antimicrobial activity of three Indian species of Brassica from Vidisha district. International $\mathrm{J}$. Inno. Sci. Res. 3:43-46.

Duncan, D.B.: A significance test for 
differences between ranked treatments in analyses of variance. - Virginia J. Sci. 2: 171-189, 1951.

Essa, A.M., Khallaf, M.K. (2014). Biological nanosilver particles for the protection of archaeological stones against microbial colonization. Int. Biodeterior. Biodegrad. 94:31-37.

Esteban, A., Abarca, M., Cabanes, F. (2005). Comparison of disk diffusion method and broth microdilution method for antifungal susceptibility testing of dermatophytes. Med. Mycol. 43:61-66.

Halliwell, B. (2007). Dietary polyphenols: good, bad, or indifferent for your health? Cardiovasc. Res. 73:341-347.

Harborne, J.B., Williams, C.A. (2000). Advances in flavonoid research since 1992. Phytochem. 55:481-504.

Hashem, M., Alamri, S. (2010). Contamination of common spices in Saudi Arabia markets with potential mycotoxinproducing fungi. Saudi J. Biol. Sci. 17:167-175.

Hassanen, N.H., Eissa, A., Sa'eb, A., Mosa, E.A. (2015). Antioxidant and antimicrobial activity of celery (Apium graveolens) and coriander (Coriandrum sativum) herb and seed essential oils. International Journal of Curr. Micro. App. Sci. 4:284-296.

Hewitt, E., Dickes, G. (1961). Spectrophotometric measurements on ascorbic acid and their use for the estimation of ascorbic acid and dehydroascorbic acid in plant tissues. Biochem. J. 78:384.

Hong, H., Landauer, M.R., Foriska, M.A., Ledney, G.D. (2006). Antibacterial activity of the soy isoflavone genistein. J. Basic Microbiol. 46:329-335.

Jiménez, N., Carrillo-Hormaza, L., Pujol, A., Álzate, F., Osorio, E., Lara-Guzman, O. (2015). Antioxidant capacity and phenolic content of commonly used anti-inflammatory medicinal plants in Colombia. Indust. Crops Prod. 70:272279.

Khan, Z., Nasreen, S. (2010). Phytochemical analysis, antifungal activity and mode of action of methanol extracts from plants against pathogens. J. Agric. Tech. 6:793-805.

Mau, J.-L., Chao, G.-R., Wu, K.-T. (2001). Antioxidant properties of methanolic extracts from several ear mushrooms. Journal of Agricultural and Food Chem. 49:5461-5467.

McDowell, L.R. (2008) Vitamins in animal and human nutrition John Wiley \& Sons.

Mohammed, A., Manish, G., Dinesh, C. (2012). Antimicrobial activity of Tinospora crispa root extracts. Int. J. Res. Aqu. Plants 3:417-419.

Mohsen, S.M., Ammar, A.S. (2009). Total phenolic contents and antioxidant activity of corn tassel extracts. Food Chem. 112:595-598.

Mora, A., Blanco, J.E., Blanco, M., Alonso, M.P., Dhabi, G., Echeita, A., González, E.A., Bernárdez, M.I., Blanco, J. (2005). Antimicrobial resistance of Shiga toxin (verotoxin)-producing Escherichia coli O157: H7 and nonO157 strains isolated from humans, cattle, sheep and food in Spain. Res. Microbiol. 156:793-806.

Muchuweti, M., Kativu, E., Mupure, C., Chidewe, C., Ndhlala, A., Benhura, M. (2007). Phenolic composition and antioxidant properties of some spices. Am. J. Food Tech. 2:414-420.

Murcia, M.A., Jiménez, A.M., Martínez-Tomé, M. (2001). Evaluation of the antioxidant properties of Mediterranean and tropical fruits compared with common food additives. J. Food Prot. 64:2037-2046.

Radwan, D.E.M., Fayez, K.A., Mahmoud, S.Y., Lu, G. (2010). Modifications of antioxidant activity and protein composition of bean leaf due to Bean yellow mosaic virus infection and salicylic acid treatments. Acta physiol. plant. 32:891-904.

Raval, B.P., Shah, T.G., Suthar, M.P., Ganure, A.L. (2010). Screening of Nigella Sativa Seeds for antifungal activity. Ann. Bio. Res. 1:164-171.

Raybaudi Massilia, R.M., MosquedaMelgar, J., SolivaFortuny, R., MartínBelloso, 
O. (2009). Control of Pathogenic and Spoilage Microorganisms in Freshcut Fruits and Fruit Juices by Traditional and Alternative Natural Antimicrobials. Comp. rev. food sci. food saf. 8:157180.

Rogozhin, E.A., Oshchepkova, Y.I., Odintsova, T.I., Khadeeva, N.V., Veshkurova, O.N., Egorov, T.A., Grishin, E.V., Salikhov, S.I. (2011). Novel antifungal defensins from Nigella sativa L. seeds. Plant Physiol. Biochem. 49:131-137.

Salman, M.T., Khan, R.A., Shukla, I. (2008). Antimicrobial activity of Black Cumin seeds (Nigella sativa) against multidrug resistant strains of Coagulase negative Staphylococci. Hippo. J.Unani Med. 3:107-112.

Sasidhran, I., A.N., M. (2010). Comparative chemical composition and antimicrobial activity of berry and leaf essential oils of Piper nigrum L. Int. J. Bio. Med. Res. 4:215-218.

Sharma, P., Jha, A.B., Dubey, R.S., Pessarakli, M. (2012). Reactive oxygen species, oxidative damage, and antioxidative defense mechanism in plants under stressful conditions. J. Bot. 2012:1-26.

Shimada, K., Fujikawa, K., Yahara, K., Nakamura, T. (1992). Antioxidative properties of xanthan on the autoxidation of soybean oil in cyclodextrin emulsion. J. agric. food chem. 40:945-948.

Shui, G., Leong, L.P. (2006). Residue from star fruit as valuable source for functional food ingredients and antioxidant nutraceuticals. Food Chem. 97:277-284.

Singleton, V.L., Rossi, J.A. (1965). Colorimetry of total phenolics with phosphomolybdic-phosphotungstic

acid reagents. Am $\mathrm{j}$ Enol Vitic. $16: 144-158$.

Srinivasan, K. (2014). Antioxidant potential of spices and their active constituents. Crit. Rev. Food Sci. Nutr. 54:352-372.

Turkoglu, A., Duru, M.E., Mercan, N., Kivrak, I., Gezer, K. (2007). Antioxidant and antimicrobial activities of Laetiporus sulphureus (Bull.) Murrill. Food Chem. 101:267-273.

Tzounis, X., Vulevic, J., Kuhnle, G.G., George, T., Leonczak, J., Gibson, G.R., KwikUribe, C., Spencer, J.P. (2008). Flavanol monomer-induced changes to the human faecal microflora. Br. J Nutr. 99:782-792.

Valacchi, G., Davis, P.A. (2008) Oxidants in biology. Springers.

Wangensteen, H., Samuelsen, A.B., Malterud, K.E. (2004). Antioxidant activity in extracts from coriander. Food Chem. 88:293-297.

Wilson, L. (2016). Spices and Flavoring Crops: Fruits and Seeds, in: Caballero, B., Finglas, P.M. and Toldrá, F. (Eds.), Encyclopedia of Food and Health, Academic Press, Oxford. pp. 73-83. 


\section{الأنشطة المضادة للأكسدة والمضادة للميكروبات للمستخلصات الميثاتولية لبعض بذور توابل الطعام}

$$
\begin{aligned}
& \text { ضياء الدين محمد رضوان "، أثرف محمد عيسي ، ضياء محمد سلطان } \\
& \text { لنبات، كلية العلوم، جامعة سو هاج } \\
& \text { نبات، كلية العلوم، جامعة الفيوم } \\
& \text { قسم الأحياء، كلية كلية العلات } \\
& \text { الميكروبات للمستخلصات في الميثانول } \\
& \text { هذه } \\
& \text { غذائية } \\
& \text { هذه المستخلصات. }
\end{aligned}
$$

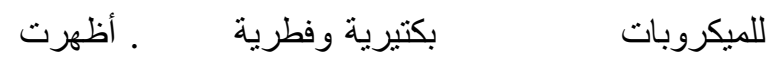

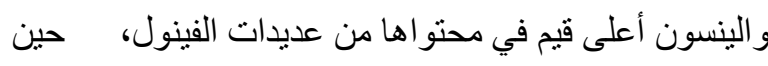

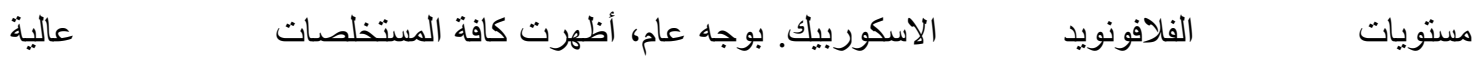

$$
\begin{aligned}
& \text { نفسه، } \\
& \text { البكتيرية. } \\
& \text { مستويات } \\
& \text { عالية } \\
& \text { الفلافونويد و عديدات الفينول } \\
& \text { أن مستخلصات بذور كل من الكمون و الكتان و الينسون و الفلفل } \\
& \text { فطرية من خلال هذا العمل، يمكن } \\
& \text { نتيجة لأنشطتها المضادة } \\
& \text { و الكزبرة والحبة السوداء لها مفيدة }
\end{aligned}
$$

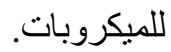

